Р.Р. Ярема ${ }^{1}$, Т.Г. Фецич ${ }^{1}$, М.А. Огорчак ${ }^{2}$, Н.А. Володько ${ }^{1}$, П.І. Гиря², Ю.Я. Ковальчук ${ }^{2}$, В.І. Сафіян², Ю.П. Милян ${ }^{2}$, М.Б. Матусяк², Ю.Ю. Олійник ${ }^{1}$, Т.І. Новіцька ${ }^{2}$, Л.І. Лаба², М.І. Яриш², М.Т. Фецич ${ }^{1}$, С.P. Фернеза ${ }^{1}$

\title{
НIPEC в комбінованому лікуванні інтраперитонеально дисемінованого раку: моноцентровий досвід проведення 215 операцій
}

\author{
${ }^{1}$ Львівський національний медичний університет ім. Данила Галицького \\ 2Львівський онкологічний регіональний лікувально-діагностичний центр \\ DOI: $10.32471 /$ clinicaloncology.2663-466X.41-1.27758
}

\begin{abstract}
Вступ. У традиційному сучасному дискурсі консервативного паліативного лікування пацієнтів з дисемінованим раком протягом останніх двох десятків років все частіше з'являються методи активної комбінованої терапії. У пацієнтів з імплантаційними метастазами різного генезу сьогодні широко застосовують метод гіпертермічної внутрішньочеревної хіміотерапії (hyperthermic intraperitoneal chemotherapy - HIPEC). Мета. Ретроспективний аналіз клінічної ефективності комбінованої терапії з використанням HIPEC у хворих на інтраперитонеально поширений рак різних локалізацій та визначення факторів прогнозу у таких пацієнтів. Матеріали та методи. Проаналізовано результати 12-річного періоду застосування НІРEC в комбінованому лікуванні хворих на місцево-поширений та дисемінований рак шлунка, первинний та рецидивний рак яєчників, колоректальний рак, псевдоміксому очеревини, саркоматоз очеревини та ін. Проведено 215 процедур НІРЕС у 211 хворих. Визначено фактори прогнозу та подальші перспективні напрямки розвитку комбінованого лікування таких хворих. Висновок. НІРЕС у складі комбінованого лікування є безпечним методом з допустимими рівнями післяопераційних ускладнень та летальності. Застосування тактики активного комбінованого лікування забезпечує тривалі терміни виживаності у відібраних хворих на інтраперитонеально поширений рак.
\end{abstract}

Ключові слова: імплантаційні метастази; карциноматоз очеревини; циторедуктивна хірургія; гіпертермічна внутрішньочеревна хіміотерапія.

\section{Вступ}

У 1980 р. американський хірург професор J.S. Spratt вперше застосував методику гіпертермічної внутрішньочеревної хіміотерапії (hyperthermic intraperitoneal chemotherapy - HIPEC) для лікування хворого на псевдоміксому очеревини [1]. Основою для комбінованого застосування інтраперитонеальної хіміотерапії та локальної гіпертермії є ряд наукових фактів. Так, локальна гіпертермія під час проведення НІРЕС проявляє прямий цитотоксичний протипухлинний ефект, посилює проникнення хіміопрепаратів у тканини, дозволяє подолати хіміорезистентність пухлин [2] та знаходиться в синергічній взаємодії з хіміотерапевтичними засобами [3]. Внаслідок існування очеревинно-плазматичного бар'єра градієнт концентрації цитостатиків великої молекулярної маси (мітоміцин, цисплатин та ін.) залишається високим протягом певного часу, що дозволяє створювати високу концентрацію хіміопрепаратів у черевній порожнині при низькій системній токсичності [4]

3 моменту першого застосування до сьогодні методика НIРЕС подолала шлях імплементації від експериментального лікування до методу з доведеною клінічною ефективністю. Сьогодні з впевненістю можна стверджувати про зміну парадигми лікування хворих на деякі інтраперитонеально дисеміновані пухлини. Так, лікувальний підхід, що включає циторедуктивні операції, НІРЕС та системну хіміотерапію, вже сьогодні стандартизовано для лікування пацієнтів 3 колоректальним раком з імплантаційними метастазами, псевдоміксомою та мезотеліомою очеревини в багатьох країнах Європейського Союзу [5, 6] та хворих на первинний рак яєчників у США [7]. Однак клінічні результати застосування НІРЕС до сьогодні залишаються обмеженими рядом ретроспективних досліджень та невеликою кількістю проспективних рандомізованих спостережень [8, 9]. Відтак, питання доцільності комбінованого лікування цієї досить контроверсійної категорії пацієнтів із перитонеальним карциноматозом залишається сьогодні актуальним, активно обговорюваним та досліджується у широкому колі рандомізованих досліджень.

Невід'ємною складовою програми комбінованого лікування хворих з перитонеальними метастазами є циторедуктивна хірургія (cytoreductive surgery - CRS). Принциповою відмінністю циторедуктивних операцій від паліативних втручань $є$ видалення не тільки локорегіонарного сегменту дисемінованої пухлини, а й віддалених метастазів. В основу циторедуктивного втручання - парціальної чи субтотальної перитонектомії (запропонованої Paul H. Sugarbaker) - покладено принцип максимального видалення макроскопових імплантаційних метастазів з черевної порожнини шляхом проведення різного характеру перитонектомій з метою досягнення мінімального мікроскопічного рівня резидуального інтраперитонеального пулу пухлинних клітин, з наступною його елімінацією під час інтраперитонеальної хіміогіпертермії [10]. Термін «циторедуктивна хірургія» на сьогодні здобув широке застосування у спеціалізованій медичній періодиці та використовується уніфіковано.

Важливим прогностичним чинником та об'єктивним критерієм стадіювання перитонеального карциноматозу є перитонеальний раковий індекс (peritoneal cancer index - PCI), шо використовується як непрямий показник можливості досягнення повного характеру циторедукції. Під час обчислення PCI черевну порожнину розділяють на 13 умовних тазовоабдомінальних ділянок, у кожній з яких залежно від розмірів імплантів оцінюється ступінь карциноматозу (від 1 до 3 балів) 3 подальшим підсумовуванням балів всіх ділянок [10].

Об'єктивним методом оцінки ступеню інтраперитонеального метастатичного поширення раку шлунка $€$ класифікація Японської асоціації з раку шлунка (Japanese Gastric Cancer Association - JGCA) [11]: Р0 - імпланти на очеревині відсутні, P1 - поодинокі дисемінати у верхньому поверсі черевної порожнини (вище рівня поперечно ободової кишки), Р2 поодинокі дисемінати у всіх відділах черевної порожнини, 
P3 - дифузний карциноматоз черевної порожнини, у тому числі наявність асциту, та CY1 - наявність злоякісних клітин у змивах з очеревини без макроскопового карциноматозу.

Вагомим прогностичним критерієм ефективності CRS $€$ показник повноти циторедукції (completeness of cytoreduction score - CC) [10]: CC-0 - макроскопові резидуальні пухлинні вогнища на очеревині після CRS відсутні, CC-1 - резидуальні вогнища діаметром не більше 2,5 мм, СС-2 - розмір резидуальних вузликів від 2,5 мм до 2,5 cм, та СС-3 - розмір резидуальних пухлинних вузлів більший за 2,5 cм.

Метою даного дослідження був ретроспективний аналіз клінічної ефективності комбінованої терапії з використанням НІРЕС у хворих на інтраперитонеально поширений рак різних локалізацій, визначення факторів прогнозу у таких пацієнтів, а також перспективних шляхів розвитку методів комбінованого лікування хворих з імплантаційними метастазами.

\section{ОБ'ЄКТ І МЕТОДИ ДОСЛІДЖЕННЯ}

Проведено аналіз ефективності застосування НІРЕС в комбінованому лікуванні 211 хворих на інтраперитонеально дисемінований рак різних локалізацій, яким було проведено 215 процедур НІРЕС. Чотирьом пацієнтам у зв'язку з тривалими термінами безрецидивного періоду НІРЕС застосовано двічі (у 2 хворих на рак яєчників та 2 хворих із псевдоміксомою очеревини). Пацієнти знаходилися на стаціонарному лікуванні у відділенні абдомінальної хірургії Львівського онкологічного регіонального лікувально-діагностичного центру у $2008-$ 2020 pр. Вік хворих становив від 22 до 76 років, середній вік$53,1 \pm 8,6$ року. Діагноз у всіх хворих пацієнтів верифіковано морфологічно, а також отримано інформовану згоду на участь у клінічному дослідженні. Стадіювання проводилося на основі критеріїв класифікації ТNM 7-го видання (2009).

Нозологічні характеристики пацієнтів представлено у табл. 1.

Хворим на рак шлунка 3 маніфестованими імплантаційними метастазами (37 хворих з синхронними та $3-3$ метахронними метастазами) проводили циторедуктивні хірургічні втручання в обсязі гастректомії чи субтотальної резекції шлунка та парціальною перитонектомією ділянок очеревини уражених імплантами, після чого інтраопераційно проводили НІРЕС. У післяопераційний період 28 пацієнтів (70\%) отримали системну хіміотерапію, 3 них 4 хворих (10\%) - периопераційну хіміотерапію FLOT-4. D0,1 лімфодисекцію виконано 8 хворим (22\%), D1+,2 лімфодисекцію - 29 пацієнтам (78\%). Середній рівень РСІ у хворих даної підгрупи становив $4,2 \pm 2,8$ бала (0-19). Розподіл хворих за підгрупами залежно

Таблиця 1. Нозологічні характеристики хворих з імплантаційними метастазами, яким проведено 215 процедур НIPEC

\begin{tabular}{|c|c|}
\hline Нозологія & $\begin{array}{c}\text { Кількість процедур } \\
\text { НIРЕС }\end{array}$ \\
\hline \multicolumn{2}{|l|}{ Рак шлунка: } \\
\hline $\begin{array}{l}\text { • } 3 \text { маніфестованими імплантаційними метаста- } \\
\text { зами (CRS + HIPEC) }\end{array}$ & 40 \\
\hline $\begin{array}{l}\text { - } 3 \text { високим ризиком інтраперитонеального ре- } \\
\text { цидиву (HIPEС в ад'ювантному режимі) }\end{array}$ & 40 \\
\hline $\begin{array}{l}\text { • із симптоматичним асцитом (HIPEC у симпто- } \\
\text { матичному режимі) }\end{array}$ & 10 \\
\hline \multicolumn{2}{|l|}{ Рак яєчників: } \\
\hline $\begin{array}{l}\text { - первинний (первинна чи інтервальна } \\
\text { CRS + HIPEC) }\end{array}$ & 18 \\
\hline - рецидивний (вторинна CRS + HIPEC) & 67 \\
\hline Псевдоміксома очеревини (CRS + HIPEC) & 19 \\
\hline Рак ободової кишки (CRS + HIPEC) & 10 \\
\hline \multicolumn{2}{|l|}{ Iнші (CRS + HIPEC): } \\
\hline • рак ендометрію & 3 \\
\hline • лейоміосаркома тіла матки & 2 \\
\hline • мезотеліома очеревини & 2 \\
\hline • GIST тонкої кишки & 2 \\
\hline • Карцинома тонкої кишки & 1 \\
\hline • Погранична серозна пухлина яєчників & 1 \\
\hline $\mathrm{y}_{\mathrm{cb} O \mathrm{O} 0}$ & 215 \\
\hline
\end{tabular}

від рівня РСІ був наступним: 0-6 балів - 32 хворих (80\%), $7-12$ балів - 6 пацієнтів (15\%) та 13 і більше балів - 2 хворих (5\%). Розподіл хворих залежно від стадії карциноматозу згідно 3 класифікацією JGCA був наступним: $\mathrm{P} 0(\mathrm{Cyt}+)-2$ хворих (5\%), P1 - 24 пацієнти (60\%), Р2 - 11 хворих (28\%) та Р3 $3(7 \%)$.

3 метою досягнення повної циторедукції хворим проводили циторедуктивні хірургічні втручання із застосуванням різних етапів операції перитонектомії за P. Sugarbaker (табл. 2). Характер досягнутої циторедукції у хворих даної групи наведено в табл. 3.

У групі хворих на рак шлунка з високим ризиком інтраперитонеального прогресування (40 пацієнтів) проводили стандартні радикальні хірургічні втручання в обсязі гастректомії чи субтотальної резекції шлунка з D1+,2 лімфаденектомією (78\%), після чого інтраопераційно проводили НІРЕС з ад'ювантною метою. Післяопераційну хіміотерапію отримали 18 хворих (45\%), з них 2 (5\%) - периопераційну хіміотерапію.

У групі хворих на рак шлунка з дифузним карциноматозом очеревини, перебіг якого ускладнювався розвитком напруженого асциту проводилися симптоматичні хірургічні втручання в обсязі лапаротомії, евакуації асциту та НIPЕС в симптоматичному режимі з метою ліквідації рецидивуючого асциту. Се-

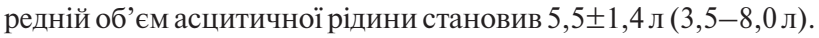
Циторедуктивний обсяг втручань у хворих даної групи не проводився у зв'язку з масивною перитонеальною дисемінацією та неможливістю досягнення повної циторедукції.

Серед 18 хворих на первинний рак яєчників 14 пацієнткам $(78 \%)$ виконано інтервальну циторедукцію після неоад'ювантної хіміотерапії, 3 (17\%) - інтервальну циторедукцію після нерадикального первинного хірургічного втручання та неоад'ювантної хіміотерапії, та 1 (5\%) - первинну циторедукцію; усі в комбінації з НІРЕС. Ад’ювантну хіміотерапію отримали 18 (100\%) пацієнток групи.

Комбіноване лікування хворих на рецидивний рак яєчників проводили із застосуванням циторедуктивних операцій в комбінації з НІРЕС з наступною системною хіміотерапією відповідної лінії. Неоад'ювантну хіміотерапію з метою регресу інтраперитонеального рецидиву проведено 25 пацієнткам (37\%) групи, післяопераційну ад’ювантну - 57 (85\%).

Середній рівень показника РСІ для двох груп хворих на рак яєчників становив $12,1 \pm 10,8$ (від 0 до 36 ) бала. Обсяги циторедуктивних втручань та характер досягнутої циторедукції у хворих на рак яєчників наведено у табл. 2 та табл. 3.

Комбіноване лікування хворих на псевдоміксому очеревини на грунті муцинозних неоплазій апендикса різних ступенів злоякісності проводили із застосуванням циторедуктивних операцій в комбінації з НІРЕС. У 12 хворих (63\%) проведено операцію суб-/тотальної парієтальної перитонектомії за P. Sugarbaker в повному обсязі (рис. 1). Прооперовано 16 хворих (84\%) з маніфестованою псевдоміксомою черевної порожнини, та 3 пацієнтів (16\%) після апендектомії в загальній хірургічній мережі з підтвердженим перфоративним мукоцеле high-grade апендикса. Середній рівень показника РСІ для хво-

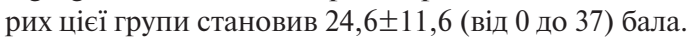

У хворих на колоректальний рак з імплантаційними метастазами проводили радикальні резекції товстої кишки, різного обсягу перитонектомії в комбінації з НІРЕС та післяопераційною системною хіміотерапією. Середній рівень показника PCI для хворих цієї групи становив $11,3 \pm 6,4$ (від 4 до 26) бала. Середній рівень показника РСІ в групі хворих з іншими пухлинами становив 17,5 $\pm 8,1$ (від 7 до 39) бала. Обсяги циторедуктивних втручань та характер повноти циторедукції у хворих різних груп наведено в табл. 2 та табл. 3.

Процедуру НІРЕС проводили за «закритою» методикою протягом 90 хв з середньою інтраабдомінальною температурою 43,4 $\pm 1,6{ }^{\circ} \mathrm{C}$ (від 39 до 44,5). У хворих на первинний рак яєчників та у платино-чутливих випадках рецидивного раку яєчників інтраперитонеально застосовували цисплатин у дозі 
Таблиця 2. Кількість етапів циторедуктивних втручань, застосованих у хворих з імплантаційними метастазами, яким проведено 215 процедур НІРЕС

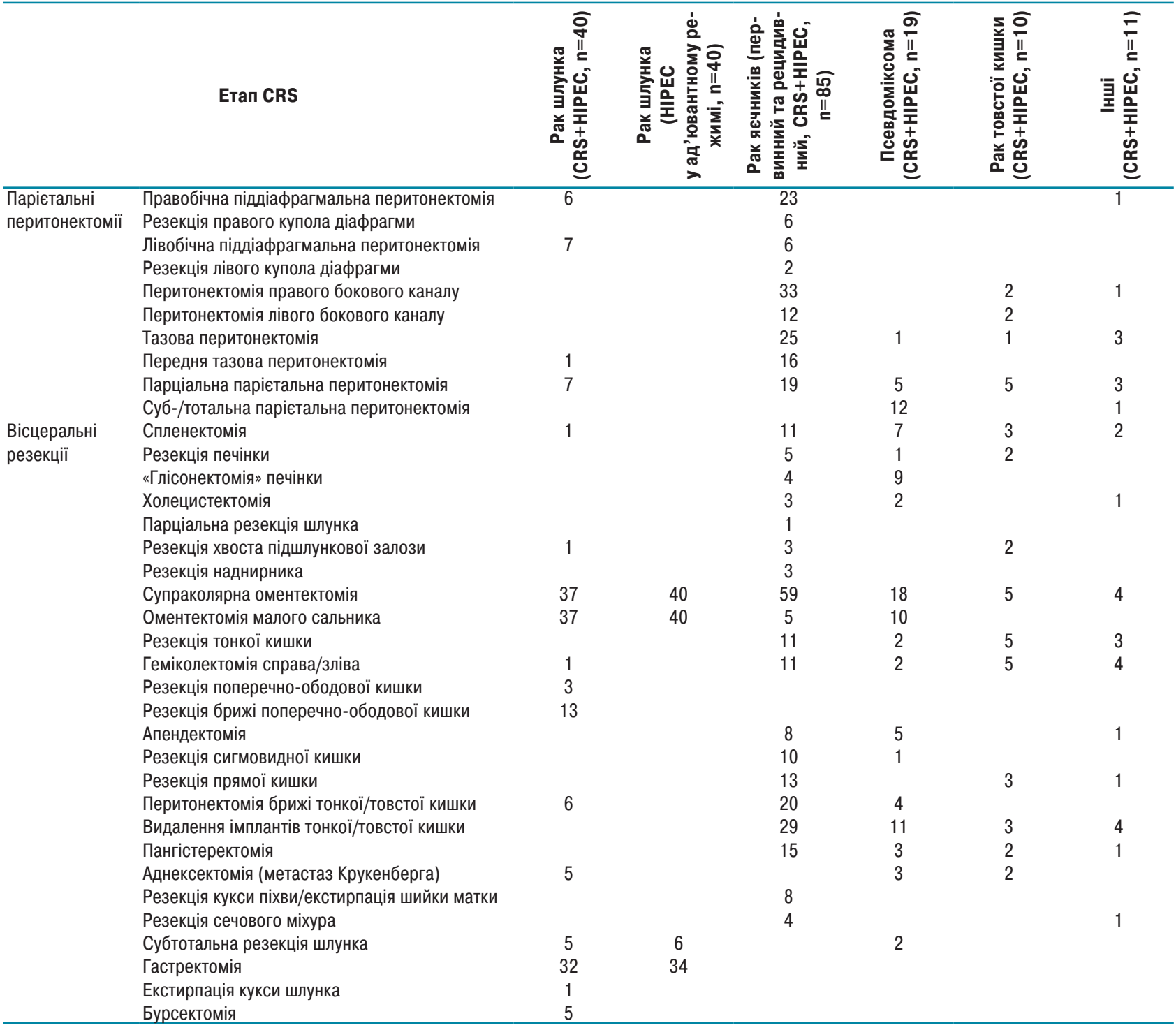

Таблиця 3. Характер циторедукції в групах хворих

\begin{tabular}{|c|c|c|c|c|c|}
\hline $\begin{array}{c}\text { Характер циторе- } \\
\text { дукції }\end{array}$ & $\begin{array}{c}\text { Рак шлунка } \\
\text { (CRS+HIPEC, n=40) }\end{array}$ & $\begin{array}{l}\text { Рак яєчників (первин- } \\
\text { ний та рецидивний, } \\
\text { CRS+HIPEC, } n=85 \text { ) }\end{array}$ & $\begin{array}{c}\text { Псевдоміксома } \\
\text { (CRS+HIPEC, n=19) }\end{array}$ & $\begin{array}{l}\text { Рак товстої кишки } \\
\text { (CRS+HIPEC, n=10) }\end{array}$ & $\begin{array}{c}\text { Інші } \\
\text { (CRS+HIPEC, } n=11)\end{array}$ \\
\hline CC-0 & 32 (80\%) & 50 (59\%) & $7(37 \%)$ & $7(70 \%)$ & $5(46 \%)$ \\
\hline CC-1 & $5(12,5 \%)$ & 19 (22\%) & $7(37 \%)$ & $2(20 \%)$ & $3(27 \%)$ \\
\hline $\mathrm{CC}-2$ & $3(7,5 \%)$ & $12(14 \%)$ & $4(21 \%)$ & $1(10 \%)$ & $3(27 \%)$ \\
\hline CC-3 & - & $4(5 \%)$ & $1(5 \%)$ & - & - \\
\hline
\end{tabular}

$100 \mathrm{Mг} / \mathrm{M}^{2}$, у разі платино-резистентних рецидивів - цисплатин у дозі 75 мг $/$ м $^{2}$ та доксорубіцин у дозі 15 мг $/ \mathrm{M}^{2}$. У хворих на рак шлунка внутрішньочеревно застосовували мітоміцин у дозі

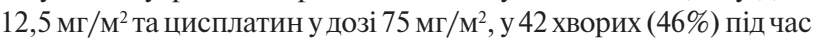
НІРЕС одночасно внутрішньовенно застосовано 5-фторурацил у дозі 400 мг $/ \mathrm{M}^{2}$ (бідирекційна хіміотерапія). У хворих на псевдоміксому очеревини інтраперитонеально застосовано мітоміцин у дозі $20 \mathrm{Mг} / \mathrm{M}^{2}$ та цисплатин $-25 \mathrm{мг} / \mathrm{M}^{2}$, у хворих на колоректальний рак - мітоміцин у дозі 20 мг/м².

Статистична обробка первинних даних проводилася з використанням програми Statistica 6. Для дослідження кумулятивної виживаності хворих використовували цензурований метод Каплана - Мейєра, визначення значущості різниці рівнів виживаності в окремих групах здійснено за допомогою логарифмічного рангового коефіцієнту.

\section{РЕЗУЛЬТАТИ ДОСЛІДЖЕННЯ}

Після проведеного хірургічного втручання з використанням НІРЕС післяопераційні ускладнення розвинулися у $71(33,7 \%)$ хворого (табл. 4 , у 6 пацієнтів зафіксовано більше одного ускладнення). У 25 (11,8\%) хворих хірургічні ускладнення вимагали проведення релапаротомії. 60-денна післяопераційна летальність становила 4,7\% (10 хворих). 3 них 6 пацієнтів характеризувалися РСІ більше 21 балів.

Мінімальний термін диспансерного спостереження за пацієнтами після комбінованого лікування становив 6 міс, максимальний - 139 міс.

Медіана загальної виживаності в групі хворих на рак шлунка $з$ маніфестованими імплантаційними метастазами, яким проводилися CRS + НIPEC становила 13,3 міс; у хворих з повною циторедукцією (СС-0) - 16,5 міс. У цій групі в терміни від 34 міс до 121 міс живими залишаються $3(7,5 \%)$ пацієнти. У $7(17,5 \%)$ хворих у віддалений період відзначено 


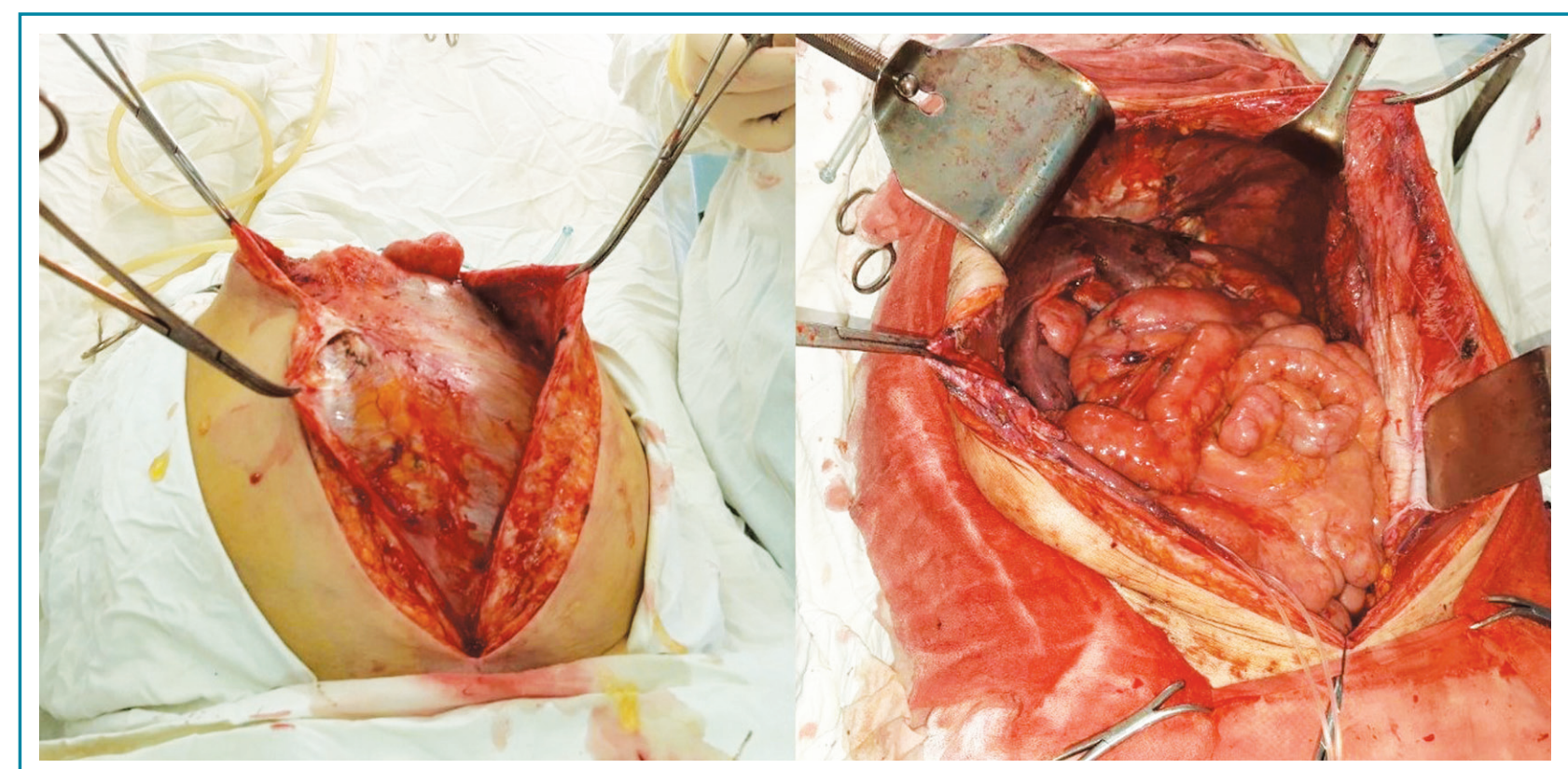

Рис. 1. Черевна порожнина хворої на псевдоміксому черевної порожнини low-grade до та після операції перитонектомії за P. Sugarbaker

Таблиця 4. Структура ускладнень після 215 хірургічних втручань 3 використанням HIPEC

Хірургічні (I-

IV ступеня відповідно до класифікації Clavien Dindo)

\section{Ускладнення}

Перфорація тонкої/товстої кишки Перфорація гострої виразки кукси шлунка

Недостатність дигестивних анастомозів Інтраабдомінальний абсцес Деструктивний панкреатит Спайкова кишкова непрохідність Внутрішньочеревна кровотеча Мезентерійний тромбоз Інтраопераційна травма сечоводу Анастомозит

Нагноєння післяопераційної рани

Ускладнення НI-

PEC (III-IV ступеня Лейкопенія III ступеня згідно 3 common Лейкопенія IV ступеня terminology criteria Нефротоксичність III ступеня for adverse events Нефротоксичність IV ступеня - CTCAE 4.0) Тромбоцитопенія III ступеня Анемія III-IV ст. (вплив також хірургічного фактора)

Системна гіпертермія під час HIPEC

Тривалий післяопераційний парез кишечнику

Соматичні

$$
\begin{aligned}
& \text { Флеботромбоз глибоких вен нижніх кін- } \\
& \text { цівок }
\end{aligned}
$$

Антибіотикоасоційований коліт Госпітальна пневмонія

\begin{tabular}{c} 
Кількість, \\
n (\%) \\
\hline $34(15,8)$ \\
5 \\
1 \\
\\
8 \\
3 \\
3 \\
3 \\
2 \\
1 \\
1 \\
1 \\
6 \\
$34(15,8)$ \\
6 \\
3 \\
5 \\
1 \\
2 \\
15 \\
1 \\
1 \\
$9(4,2)$ \\
2 \\
5 \\
2 \\
\hline
\end{tabular}

розвиток метахронних метастазів екстраперитонеальних локалізацій (кістки, легені, лімфатичні вузли тощо) без розвитку інтраперитонеального рецидиву. Медіана загальної виживаності у хворих на рак шлунка з високим ризиком інтраперитонеального прогресування та ад’ювантним НІРЕС становила 36 міс (рис. 2). У групі хворих із симптоматичним асцитом застосування НІРЕС забезпечило ліквідацію асциту у $8(80 \%)$ хворих.

У хворих на рецидивний рак яєчників медіана загальної виживаності становила 45 міс. У монофакторному аналізі статис-

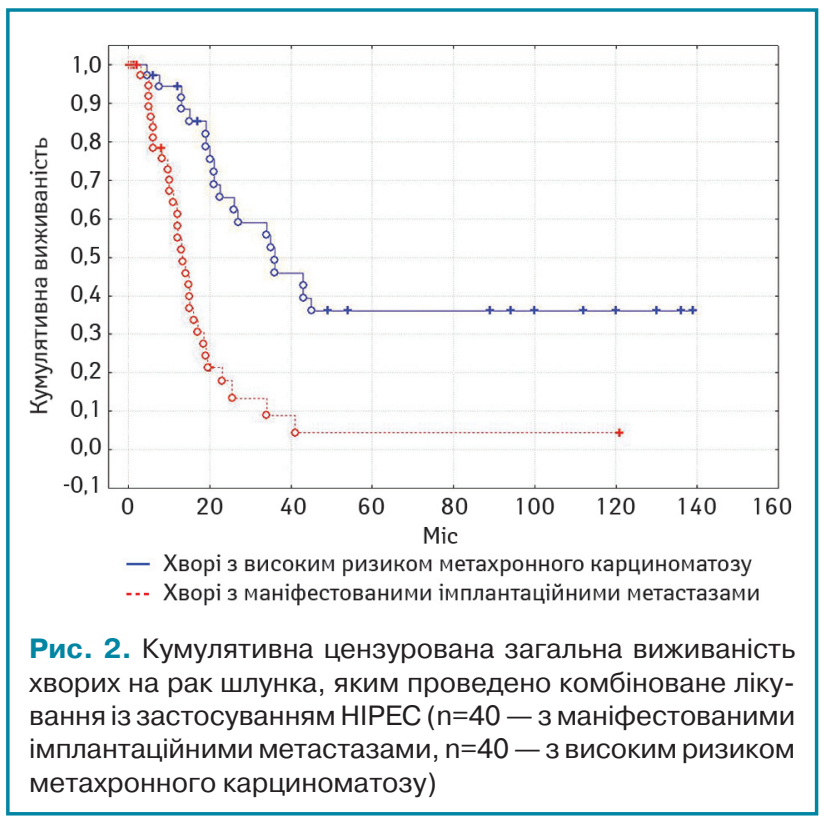

тично вірогідним прогностичним впливом характеризувалися: наявність асциту, хіміочутливість та тривалість безрецидивного періоду, перитонеальний індекс раку (рис. 3), ступінь повноти циторедукції (рис. 4), а також наявність екстраперитонеальних метастазів. Медіана загальної виживаності у хворих на первинний рак яєчників становиа 39 міс.

У хворих на муцинозні неоплазії апендикса, ускладнені псевдоміксомою очеревини, медіани загальної виживаності не досягнуто. Більшість хворих були живими в терміни від 10 міс до 48 міс після проведеного комбінованого лікування (рис. 5). У хворих на інтраперитонеально дисемінований колоректальний рак медіану загальної виживаності зафіксовано на рівні 26 міс.

\section{ОБГОВОРЕННЯ РЕЗУЛЬТАТІВ}

Результати даного ретроспективного дослідження засвідчили, що застосування агресивної тактики комбінованого лікування інтраперитонеально дисемінованого раку з використанням НIPEC є безпечним методом лікування, що супрово- 


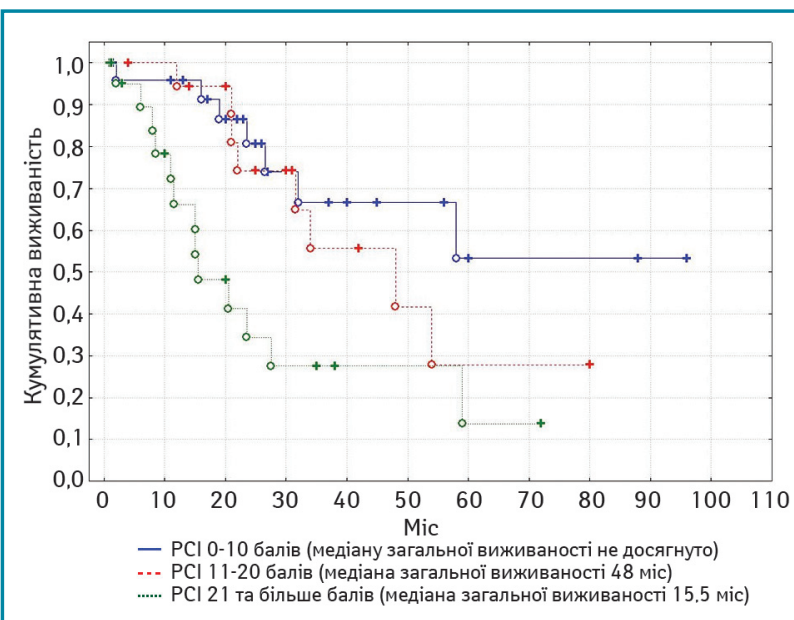

Рис. 3. Кумулятивна цензурована загальна виживаність хворих на рецидивний рак яєчників, яким проведено комбіноване лікування із застосуванням HIPEC залежно від $\mathrm{PCl}(p=0,0032)$

джується допустимими рівнями післяопераційних ускладнень та летальності. Більшість випадків післяопераційних ускладнень були хірургічного характеру (хірургічні ускладнення розвинулися у 15,8 \% хворих), що пов'язано з екстенсивним обсягом циторедуктивних втручань. Найчастішим ускладненням процедури НІРЕС була нефротоксичність. Проте тяжка нефротоксичність (III-IV ступеня) розвинулася лише у 2,8\% хворих.

В актуальних міжнародних клінічних рекомендаціях $\mathrm{CB}_{\text {в- }}$ ропейського товариства медичної онкології (Eupopean society of medical oncology - ESMO) йдеться про те, що гастректомія у хворих на рак шлунка з лімітованим метастатичним процесом не призводить до збільшення виживаності (рівень доказовості IA) [12]. Відтак, застосування CRS+HIPEC у хворих на рак шлунка $з$ імплантаційними метастазами сьогодні не рекомендоване за межами клінічних досліджень [12]. Проте японські хірурги у 2005 р. за результатами ретроспективного дослідження повідомляли про медіану загальної виживаності 15,5 міс та 5-річну виживаність на рівні $27 \%$ у пацієнтів 3 повною циторедукцією (CС-0) [13]. Група французьких онкологів у 2019 р. повідомила про досягнення медіани загальної виживаності 18,8 міс, а також 3- та 5-річної виживаності на рівні 26,21 та 19,87\% у майже трьох сотень хворих [14]. За результатами кооперативного Центрально-східноєвропейського дослідження повідомлялося про медіану та 1-річну виживаність на рівні 15 міс та 69\% у хворих з P1 (JGCA) дисемінацією та повною циторедукцією [15]. Результати даного ретроспективного аналізу також зафіксували медіану виживаності хворих на рак шлунка з імплантаційними метастазами на рівні 16,5 міс після повної циторедукції та НІРЕС, що, очевидно, перевищує ефективність застосування консервативного підходу. Випадки відсутності інтраперитонеального рецидиву у хворих даної групи свідчать про якісні зміни процесів інтраперитонеального канцерогенезу на фоні комбінованого лікування. Відтак, сьогодні досить актуальними є результати відповідних проспективнивних рандомізованих досліджень [16].

Місцево-поширений рак шлунка у значній кількості випадків на момент операції супроводжується субклінічною перитонеальною дисемінацією, про що свідчить маніфестація карциноматозу вже протягом перших місяців чи років після лікування. Тому доволі перспективною видається ідея застосування НІРЕС в ад'ювантному режимі у таких хворих, що підтверджується результатами даного ретроспективного аналізу. Два метааналізи попередніх років засвідчили перевагу такого комбінованого лікування порівняно з групою хірургічного контролю $[17,18]$. Підтвердження ефективності НІРЕС

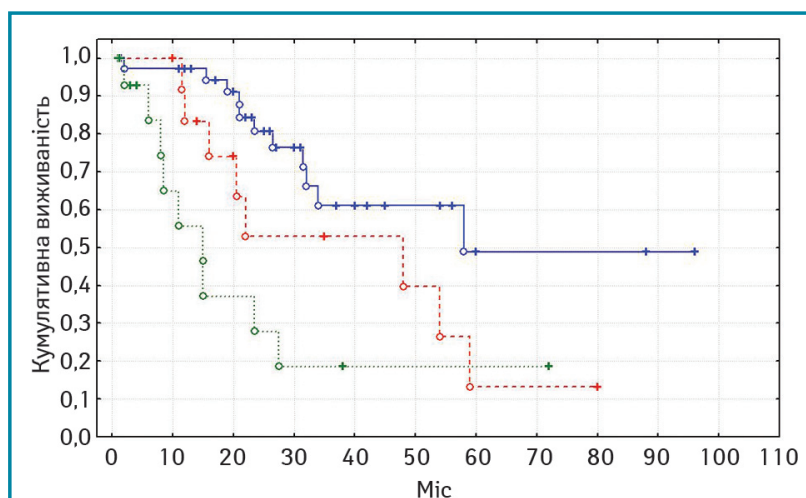

- Ступінь циторедукції СС-0 (медіана загальної виживаності 58 міс) ..- Ступінь циторедукції СС-1 (медіана загальної виживаності 48 міс) ...... Ступінь циторедукції СС-2,3 (медіана загальної виживаності 15 міс)

Рис. 4. Кумулятивна цензурована загальна виживаність хворих на рецидивний рак яєчників, яким проведено комбіноване лікування із застосуванням HIPEC залежно від ступеня повноти циторедукції ( $p=0,0016)$

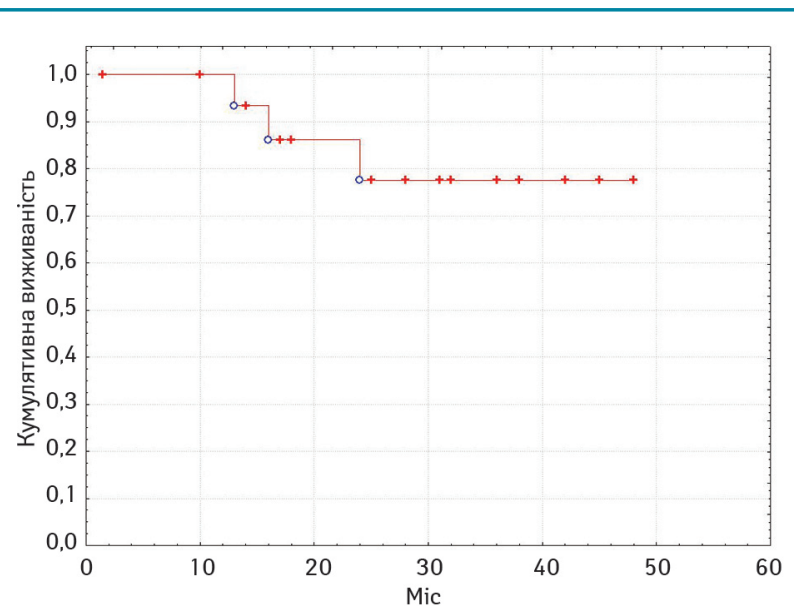

Рис. 5. Кумулятивна цензурована загальна виживаність хворих на псевдоміксому очеревини, яким проведено комбіноване лікування із застосуванням HIPEC

в ад’ювантному режимі у хворих на рак шлунка очікується після завершення Європейського рандомізованого дослідження GASTRICHIP [19].

Абсолютну більшість хворих даного ретроспективного аналізу становили пацієнтки з рецидивним раком яєчників. Групою італійських онкологів [20] представлено результати мультицентрового дослідження ефективності CRS+HIPEC у комбінованому лікуванні хворих на рецидивний рак яєчників, що отримували лікування у 4 спеціалізованих центрах. Середнє значення показника РСІ у хворих становило 15,2 бала. Післяопераційні ускладнення та летальність розвинулися у 26,3 та 5,3\% хворих відповідно. Медіана безрецидивної та загальної виживаності хворих у даному дослідженні становили 10,8 міс та 25,7 міс відповідно. Безпосередні та віддалені результати нашого дослідження відповідають результатам цього дослідження та повідомленням низки інших авторів [21]. PCI та ступінь повноти циторедукції є традиційними прогностичними факторами під час проведення CRS та HIPEC, що широко висвітлені в літературі, у тому числі для хворих на рак яєчників [20, 22, 23]. Результати нашого дослідження також підтвердили прогностичну цінність цих критеріїв у рамках монофакторного аналізу.

У 2018 р. групою нідерландських онкологів на чолі iз Willemien van Driel [24] в авторитетному виданні «The New England Journal of Medicine» оприлюднено результати мульти- 
центричного рандомізованого дослідження III фази застосування НІРЕС під час інтервальної циторедукції у хворих на первинний рак яєчників. Медіану загальної виживаності в дослідній групі зафіксовано на рівні 45,7 міс на фоні 33,9 міс групи контролю $(\mathrm{p}=0,02)$ при однаковому рівні післяопераційних ускладнень. Результати цього проспективного дослідження лягли в основу чинного на сьогодні Північноамериканського стандарту Національної комплексної онкологічної мережі (National Comprehensive Cancer Network - NCCN) для хворих на первинний рак яєчників [7], а їх імплементація в клінічну практику видається доволі перспективною.

Ще у 2003 р. опубліковано результати рандомізованого дослідження застосування CRS+HIPEC у хворих на інтраперитонеально дисемінований колоректальний рак [25], що засвідчили подвійне зростання медіани виживаності порівняно з групою паліативної хіміотерапії та лягли в основу чинного на сьогодні Європейського стандарту лікування таких хворих. Проте у 2018 р. на щорічній конференції ASCO групою французьких онкологів оприлюднено результати [9] рандомізованого дослідження PRODIGE7, де в групі CRS+HIPEC за умови повної циторедукції зафіксовано медіану загальної виживаності на рівні 41,7 міс, тоді як в контрольній групі CRS (теж після повної циторедукції) - на рівні 41,2 міс $(\mathrm{p}=0,995)$. Відтак сьогодні ведуться активні дискусії щодо внеску НІРЕС в загальну ефективність комбінованого лікування хворих на колоректальний рак з імплантаційними метастазами, та потенційної зміни Європейського стандарту. Проте абсолютно безсумнівною сьогодні виглядає лише теза про неможливість досягнення медіани виживаності більше 40 міс на основі консервативного підходу без застосування тактики агресивної CRS у хворих цієї категорії.

Застосування тактики CRS+HIPEC є сьогодні «золотим стандартом» терапії хворих на муцинозні неоплазії апендикса з розвитком синдрому псевдоміксоми очеревини, що підтверджується даними літератури [26, 27] та результатами цього дослідження.

Результати застосування НІРЕС в комбінованому лікуванні рідкісних форм захворювань 3 інтраперитонеальним поширенням (саркоматоз очеревини, гастроінтестинальна стромальна пухлина, рак ендометрію та ін.) обмежені поодинокими літературними повідомленнями $[28,29]$ та вимагають подальших досліджень.

\section{ВИСНОВКИ}

Отже, беручи до уваги клінічні результати даного моноцентрового досвіду та дані літературних публікацій останніх років можна робити наступні висновки. НІРЕС у складі комбінованого лікування є безпечним методом з допустимими рівнями післяопераційних ускладнень та летальності.

Застосування CRS+HIPEC у хворих на рак шлунка з обмеженими стадіями перитонеальної дисемінації забезпечує достовірне зростання виживаності, зокрема до 16,5 міс за умови повної циторедукції в даному дослідженні. Даний підхід вимагає підтвердження результатами рандомізованих досліджень. Доволі перспективним є застосування НІРЕС в ад'ювантному режимі у хворих на рак шлунка з високим ризиком інтраперитонеального рецидиву. Результати клінічних досліджень 3 цього приводу очікуються найближчими роками.

Використання CRS, HIPEC та системної хіміотерапії в комбінованому лікуванні хворих на рецидивний рак яєчників в рамках даного дослідження забезпечило медіану виживаності на рівні 45 міс. Факторами прогнозу з вірогідним впливом на виживаність визначено: наявність асциту, хіміочутливість та тривалість безрецидивного періоду, перитонеальний індекс раку, ступінь повноти циторедукції та наявність екстраперитонеальних метастазів. Однак таке комбіноване лікування цієї категорії хворих поки не регламентоване жодними національними чи міжнародними клінічними рекомендаціями. Ефективним є застосування НIPЕС у хворих на первинний рак яєчників, що підтверджується американськими (NCCN) стандартами для випадків інтервальної циторедукції.

Використання CRS та HIPEC у хворих на колоректальний рак з імплантаційними метастазами значно підвищує виживаність порівняно з консервативним підходом. Проте внесок НІРЕС у загальне зростання виживаності на фоні комбінованого лікування є дискутабельним питанням.

Застосування субтотальної перитонектомії + НІРЕС є сьогодні «золотим стандартом» терапії хворих на псевдоміксому очеревини, що підтверджується національними рекомендаціями багатьох європейських країн та результатами даного дослідження.

Використання НІРЕС в комбінованому лікуванні рідкісних форм захворювань з інтраперитонеальним поширенням (саркоматоз очеревини, гастроінтестинальна стромальна пухлина, рак ендометрію та ін.) вимагає подальших досліджень.

\section{СПИСОК ВИКОРИСТАНОЇ ЛІТЕРАТУРИ}

1. Spratt, J. S., Adcock, R. A., Muskovin, M., Sherrill, W., \& McKeown, J. (1980). Clinical delivery system for intraperitoneal hyperthermic chemotherapy. Cancer Research, 40(2), 256-260.

2. Suit, H. D., \& Gerweck, L. E. (1979). Potential for hyperthermia and radiation therapy. Cancer Research, 39(6), 2290-2298.

3. Watanabe, M., Tanaka, R., Hondo, H., \& Kuroki, M. (1992). Effects of antineoplastic agents and hyperthermia on cytotoxicity toward chronically hypoxic glioma cells. International Journal of Hyperthermia, 8(1), 131-138. DOl.org/10.3109/02656739209052885.

4. Van der Speeten, K., Stuart, O. A., Chang, D., Mahteme, H., \& Sugarbaker, P. H. (2011). Changes induced by surgical and clinical factors in the pharmacology of intraperitoneal mitomycin C in 145 patients with peritoneal carcinomatosis. Cancer Chemotherapy and Pharmacology, 68(1), 147-156. doi: 10.1007/s00280-010-1460-4.

5. Elias, D., Gilly, F., Quenet, F., Bereder, J.M., Sidéris, L., Mansvelt, B. Glehen, O., Association Française de Chirurgie (2010). Pseudomyxoma peritonei: a French multicentric study of 301 patients treated with cytoreductive surgery and intraperitoneal chemotherapy. Europen Journal of Surgical Oncology, 36(5), 456-462. doi: 10.1016/j.ejso.2010.01.006.

6. Baratti, D., Scivales, A., Balestra, M. R., Ponzi, P., Di Stas, F., Kusamura, S. Deraco, M. (2010). Cost analysis of the combined procedure of cytoreductive surgery and hyperthermic intraperitoneal chemotherapy (HIPEC). Europen Journal of Surgical Oncology, 36(5), 463-469. doi: 10.1016/j.ejso.2010.03.005.

7. Armstrong, D. K., Alvarez, R. D., Bakkum-Gamez, J. N., Barroilhet, L., Behbakht, K., Berchuck, A., ... Engh, A.M. (2019). NCCN Guidelines Insights: Ovarian Cancer, Version 1.2019. Journal of the National Comprehensive Cancer Network, 7(8), 896-909. doi: 10.6004/jnccn.2019.0039.

8. Spiliotis, J., Halkia, E., Lianos, E., Kalantzi, N., Grivas, A., Efstathiou, E., \& Giassas, S. (2015). Cytoreductive surgery and HIPEC in recurrent epithelial ovarian cancer: a prospective randomized phase III study. Annals of Surgical Oncology, 22(5), 1570-1575. doi: 10.1245/s10434-014-4157-9.

9. Quenet, F., Elias, D., Roca, L., Goere, D., Ghouti, L., Pocard, M., ... Glehen, O. (2018). A UNICANCER phase III trial of hyperthermic intra-peritoneal chemotherapy (HIPEC) for colorectal peritoneal carcinomatosis (PC): PRODIGE7. Journal of Clinical Oncology, 36(18 suppl): LBA3503-LBA3503.

10. Sugarbaker, P.H. (1999). Management of peritoneal-surface malignancy: the surgeon's role. Langenbeck's Archives of Surgery, 384(6): 576-587. doi: $10.1007 / \mathrm{s} 004230050246$.

11. Japanese Gastric Cancer Association (1998). Japanese classification of gastric cancer. $-2^{\text {nd }}$ English ed. Gastric Cancer, 1(1), 10-24. doi: 10.1007/s101209800016.

12. Smyth, E. C., Verheij, M., Allum, W., Cunningham, D., Cervantes, A., \& Arnold, D. (2016). Gastric cancer: ESMO Clinical Practice Guidelines for diagnosis, treatment and follow-up. Annals of Oncology, 27(suppl5), v38-v49. doi: 10.1093/annonc/mdw350.

13. Yonemura Y., Kawamura T., Bandou E., Takahashi S., Sawa T., Matsuki N. (2005) Treatment of peritoneal dissemination from gastric cancer by peritonectomy and chemohyperthermic peritoneal perfusion. British Journal of Surgery, 92(3), 370-375. doi: $10.1002 /$ bjs.4695

14. Bonnot, P. E., Piessen, G., Kepenekian, V., Decullier, E., Pocard, M., Meunier, B.... Glehen, O. (2019). Cytoreductive Surgery With or Without Hyperthermic Intraperitoneal Chemotherapy for Gastric Cancer With Peritoneal Metastases (CYTOCHIP study): A Propensity Score Analysis Journal of Clinical Oncology, 37(23), 2028-2040. doi: 10.1200/JCO.18.01688

15. Yarema, R., Mielko, J., Fetsych, T., Ohorchak, M., Skorzewska, M., RawiczPruszyński, K., ... Paskonis, M. (2019). Hyperthermic intraperitoneal chemotherapy (HIPEC) in combined treatment of locally advanced and intraperitonealy disseminated gastric cancer: A retrospective cooperative Central-Eastern European study. Cancer Medicine, 8(6), 2877-2885. doi: 10.1002/cam4.2204.

16. Koemans, W. J., van der Kaaij, R. T., Boot,H., Buffart, T., Veenhof, A. A. F. A., Hartemink, K. J., ... van Sandic, J. W. (2019). Cytoreductive surgery and hyperthermic intraperitoneal chemotherapy versus palliative systemic chemotherapy in stomach cancer patients with peritoneal dissemination, the study protocol of a multicentre randomised controlled trial (PERISCOPE II). BMC Cancer, 19(1), 420. doi: 10.1186/s12885-019-5640-2.

17. Yan, T. D., Black, D., Sugarbaker, P. H., Zhu, J., Yonemur, Y., Petrou, G., \& Morris, D. L. (2007). A systematic review and meta-analysis of the randomized controlled trials on adjuvant intraperitoneal chemotherapy for resectable gastric cancer. Annals of Surgical Oncology, 14(10), 2702-13. doi: 10.1245/s10434-007-9487-4.

18. Xu, D. Z., Zhan, Y. Q., Sun, X. W., Cao, S. M., \& Geng, Q. R. (2004). Meta-analysis of intraperitoneal chemotherapy for gastric cancer. World Journal of Gastroenterology, 10(18), 2727-30. doi: 10.3748/wjg.v10.i18.2727.

19. Glehen, O., Passot, G., Villeneuve, L., Vaudoyer, D., Bin-Dorel, S., Boschetti, G., ... Garofalo, A. (2014). GASTRICHIP: D2 resection and hyperthermic intraperitoneal chemotherapy in locally advanced gastric carcinoma: a randomized and multicenter phase III study. BMC Cancer, 14,183.doi: 10.1186/1471-2407-14-183. 
20. Deraco, M., Virzì, S., lusco, D. R., Puccio, F., Macrì, A., Famulari, C., Kusamura, S. (2012) Secondary cytoreductive surgery and hyperthermic intraperitonea chemotherapy for recurrent epithelial ovarian cancer: a multi-institutional study. BJOG, 119(7), 800-9. doi: 10.1111/j.1471-0528.2011.03207.x.

21. Helm, C. W., Randall-Whitis, L., Martin, R. S., Metzinger, D. S., Gordinier, M. E., Parker, L. P., \& Edwards, R. P. (2007). Hyperthermic intraperitoneal chemotherapy in conjunction with surgery for the treatment of recurrent ovarian carcinoma Gynecological Oncology, 105(1), 90-6. doi:10.1016/j.ygyno.2006.10.051.

22. Fagotti, A., Paris, I., Grimolizzi, F., Fanfani, F., Vizzielli, G., Naldini, A., \& Scambia, G. (2009). Secondary cytoreduction plus oxaliplatin-based HIPEC in platinumsensitive recurrent ovarian cancer patients: a pilot study. Gynecological Oncoly, 113(3), 335-40. doi: 10.1016/j.ygyno.2009.03.004.

23. Cavaliere D., Cirocchi R., Coccolini F., Fagotti A., Fambrini M., Federici O., ... Valle M. (2017). 1st Evidence-based Italian consensus conference on cytoreductive surgery and hyperthermic intraperitoneal chemotherapy for peritoneal carcinosis from ovarian cancer. Tumori, 103(6), 525-536. doi: 10.5301/tj.5000623.

24. van Driel, W.J., Koole, S.N., Sikorska, K., van Leeuwen, J. H. S., Schreuder, H. W. R., Hermans, R. H. M., ... Sonke, J. S. (2018). Hyperthermic Intraperitonea Chemotherapy in Ovarian Cancer. The New England Journal of Medicine, 378, 230-240. doi: 10.1056/NEJMoa1708618.

25. Verwaal, V. J., van Ruth, S., de Bree, E., van Sloothen, G. W., van Tinteren, H., Boot, H., \& Zoetmulder, F. A. N. (2003). Randomized trial of cytoreduction and hyperthermic intraperitoneal chemotherapy versus systemic chemotherapy and palliative surgery in patients with peritoneal carcinomatosis of colorectal cancer. Journal of Clinical Oncology, 21(20), 3737-43. doi: 10.1200/JCO.2003.04.187.

26. Moran, B., Baratti, D., Yan, T. D., Kusamura, S., \& Deraco, M. (2008) Consensus statement on the loco-regional treatment of appendiceal mucinous neoplasms with peritoneal dissemination (pseudomyxoma peritonei). Journal of Surgical Oncology, 98(4), 277-82. doi: 10.1002/jso.21054.

27. Moran, B., Cecil, T., Chandrakumaran, K., Arnold, S., Mohamed, F., \& Venkatasubramaniam, A. (2015). The results of cytoreductive surgery and hyperthermic intraperitoneal chemotherapy in 1200 patients with peritoneal malignancy. Colorectal Disease, 17(9), 772-8. doi: 10.1111/codi.12975.

28. Díaz-Montes, T. P., El-Sharkawy, F., Lynam, S., Harper, A., Sittig, M., MacDonald, R., ... Sardi, A. (2018). Efficacy of Hyperthermic Intraperitonea Chemotherapy and Cytoreductive Surgery in the Treatment of Recurrent Uterine Sarcoma. International Journal of Gynecological Cancer, 28(6), 1130-1137. doi: 10.1097/IGC.0000000000001289.

29. Bryan, M. L., Fitzgerald, N. C., Levine, E. A., Shen, P., Stewart, J. H., \& Votanopoulos, K. I. (2014). Cytoreductive surgery with hyperthermic intraperitoneal chemotherapy in sarcomatosis from gastrointestinal stromal tumor. American Surgeon 80(9), 890-895. PMID: 25197876.

\section{НIPEC в комбинированном лечении}

интраперитонеально диссеминированного рака: моноцентровой опыт проведения 215 операций

Р.Р. Ярема ${ }^{1}$, Т.Г. Фецич ${ }^{1}$ М.А. Огорчак², Н.А. Володько ${ }^{1}$, П.И. Гиря², Ю.Я. Ковальчук², В.И. Сафиян ${ }^{2}$ Ю.П. Милян ${ }^{2}$, М.Б. Матусяк²,

Ю.Ю. Олийник', Т.И. Новицкая 2 Л.И. Лаба'ㄹ, М.И. Ярыш²,

M.T. Фецич ${ }^{\prime}$, С.P. Фернеза

'Львовский национальный медицинский университет им. Данила Галицкого

2Львовский онкологический региональный лечебнодиагностический центр

Резюме. Введение. В традиционном современном дискурсе консервативного паллиативного лечения диссеминированного рака в течение последних двух десятков лет все чаще появляются методы активного комбинированного лечения таких больных. У пациентов с имплантационными метастазами различного генеза сегодня широко применяют метод гипертермической внутрибрюшной химиотерапии (hyperthermic intraperitoneal chemotherapy - HIPEC). Цель. Ретроспективный анализ клинической эффективности комбинированной терапии с использованием НІРЕС у больных интраперитонеально распространенным раком различных локализаций и определение факторов прогноза у таких пациентов. Материалы и методы. Проанализированы результаты 12-летнего периода применения НІРЕС в комбинированном лечении больных с местно-распространенным и диссеминированным раком желудка, первичным и рецидивирующим раком яичников, колоректальным раком, псевдомиксомой брюшины, сарко- матозом брюшины и др. Проведены 215 процедур НІРЕС у 211 больных. Определены факторы прогноза и дальнейшие перспективные направления развития комбинированного лечения таких пациентов. Выводы. НІРЕС в составе комбинированного лечения является безопасным методом с допустимыми уровнями послеоперационных осложнений и летальности. Применение тактики активного комбинированного лечения обеспечивает длительные сроки выживаемости у отобранных больных с интраперитонеально распространенным раком.

Ключевые слова: имплантационные метастазы; карциноматоз брюшины; циторедуктивная хирургия; гипертермическая внутрибрюшная химиотерапия.

\section{HIPEC in combined treatment of intraperitoneally disseminated cancer: a monocentric experience of $\mathbf{2 1 5}$ operations}

R.R. Yarema ${ }^{\text {, T.G. Fetsych }}{ }^{1}$, M.A. Ohorchak ${ }^{2}$, N.A. Volodko ${ }^{1}$, P.I. Gyrya ${ }^{2}$, Y.Y. Kovalchuk', V.I. Safiyan' ${ }^{2}$,Y.P. Mylyan ${ }^{2}$, M.B. Matusyak', Y.Y. Oliynyk ${ }^{1}$, T.I. Novitska ${ }^{2}$, L.I. Laba ${ }^{2}$,

M.I. Yarysh ${ }^{2}$, M.T. Fetsych ${ }^{1}$, S.R. Ferneza ${ }^{1}$

'Danylo Halytsky Lviv National Medical University

${ }^{2}$ Lviv Oncological Regional Medical and Diagnostic Center

Resume. Introduction. In the traditional modern discourse of conservative palliative treatment of disseminated cancer over the past two decades, methods of active combined treatment of such patients have become increasingly common. The method of hyperthermic intraperitoneal chemotherapy (HIPEC) is widely used today for patients with peritoneal metastases of various genesis, Aim. Retrospective analysis of clinical efficacy of combined therapy using HIPEC in patients with intraperitoneally disseminated cancer of different localizations and determination of prognostic factors for such patients. Materials and methods. The results of a 12-year period of HIPEC use in the combined treatment of patients with locally advanced and disseminated gastric cancer, primary and recurrent ovarian cancer, colorectal cancer, peritoneal pseudomyxoma, peritoneal sarcomatosis, etc. were analyzed. 215 HIPEC procedures were performed for 211 patients. The prognostic factors and further perspective directions of development of combined treatment of such patients are determined. Conclusion. Combined therapy with HIPEC is a safe method with acceptable levels of postoperative morbidity and mortality. The use of active combined therapy tactics ensures long survival in selected patients with intraperitoneally disseminated cancer.

Key words: peritoneal metastases; peritoneal carcinomatosis; cytoreductive surgery; hyperthermic intraperitoneal chemotherapy.

Aдреса:

Ярема Роман Романович

79000, Львів, вул. Пекарська, 69

Львівський наиіональний медичний університет ім. Данила Галииького

Тел.: (067) 940-69-33; (032) 295-37-61

E-mail: roman.yarema@ukr.net 